\title{
PENGGUNAAN MODEL PEMBELAJARAN HYPERTEXT DAN HYPERMEDIA DENGAN BLENDED LEARNING TERHADAP HASIL BELAJAR
}

\author{
Samsul Susilawati \\ UIN Maulana Malik Ibrahim Malang
}

\begin{abstract}
Hypertext and hypermedia are kinds of media software that interlink of text, image, graphic, video, and audio. The use of hypertext and hypermedia as a method on a blended learning situation make learning activity more interactive. Users can make connection between text, image, audio clips and video clips as a link or hyperlink. Cooperative skills of students in the methods Hypertex and Hypermedia through Blended Learning in social studies integrated together and learning process with the full meaning, because it is not only related to the achievement of the learning material, but students also learn to operate the computer well and social life when discussions group.The use of hypertext and hypermedia is effective to motivate students learning on of social science. It can also effective to enhance students learning achievement on social science.
\end{abstract}

Key words: Hypertext and hyperlink; blended learning

\section{A. Pendahuluan}

Ilmu Sosial adalah suatu bahan kajian yang terpadu yang merupakan penyederhanaan, adaptasi, seleksi dan modifikasi yang diorganisasikan dari konsepkonsep dan keterampilan-keterampilan Sejarah, Geografi, Sosiologi, Antropologi, dan Ekonomi.

Geografi, sejarah, dan anpropologi merupakan disiplin ilmu yang memiliki keterpaduan yang tinggi. Pembelajaran geografi memberikan kebulatan wawasan yang berkenaan dengan wilayah-wilayah, sedangkan sejarah memberikan wawasan berkenaan dengan peristiwa-peristiwa dari berbagai periode. Antropologi meliputi studi-studi komparatif yang berkenaan dengan nilai-nilai, kepercayaan, struktur social, aktivitas-aktivitas ekonomi, organisasi politik, ekspresi-ekspresi dan spiritual, teknologi, dan benda-benda budaya dari budaya-budaya terpilih. Ilmu politik dan ekonomi tergolong ke dalam ilmu-ilmu tentang kebijakan pada aktivitas-aktivitas yang berkenaan dengan pembuatan keputusan. Sosiologi dan psikologi sosial merupakan ilmu-ilmu tentang perilaku seperti konsep peran, kelompok, institusi, 
proses interaksi dan kontrol peran, kelompok, institusi, proses interaksi dan kontrol sosial. Secara intesif konsep-konsep seperti ini digunakan ilmu-ilmu sosial dan studistudi sosial.

Bentuk pemanfaatan TIK yang mutakhir dalam pembelajaran adalah proses pembelajaran maya atau yang dikenal dengan istilah virtual learning (dikenal juga sebagai e-learning). Proses pembelajaran maya terjadi pada kelas maya (virtual classroom) dan atau universitas maya (virtual university) yang berada dalam cyberspace (dunia cyber) melalui jaringan internet. Proses pembelajaran maya berintikan keterpisahan ruang dan waktu antara mahasiswa dan dosen, serta sistem belajar terbuka - yang berintikan akses yang terbuka dan kebebasan memilih ragam sumber belajar serta alur proses belajar oleh mahasiswa. Pembelajaran maya yang memanfaatkan the world wide web (www) pada prinsipnya memberikan apa yang diinginkan setiap orang (dalam beragam bentuk), di tempat yang diinginkannya, pada saat yang diinginkannya (to give what people want, where they want it, and when they want it - www).

Ketika mengajarkan suatu mata pelajaran tertentu, materi dapat didistribusikan dalam bentuk hypertext dan hypermedia. Jika si belajar merasa kurang dalam bagian materi tersebut, maka si belajar yang bersangkutan bisa mengunjungi halaman tersebut untuk pendalaman atau pemerkayaan pengetahuannya. Hal seperti ini sudah cukup banyak dilakukan di dunia industri teknologi informasi, dimana vendor-vendor besar teknologi seperti Microsoft, Oracle, ataupun Cisco banyak membuat buku-buku elektronik berbasis Hypertext atau yang sejenisnya untuk memudahkan orang dengan latar belakang kemampuan yang berbeda mempelajari sesuatu teknologi yang sama.

Bentuk pembelajaran model blended ini, mampu mengkombinasikan interaksi personal dalam pertemuan di kelas secara langsung dengan pendidikan online yang mempunyai fleksibilitas belajar yang tinggi. Proses belajar dapat ditingkatkan dengan cara mengaitkan materi pembelajaran yang tersedia secara online pada saat apapun ketika pebelajar butuh untuk mengaksesnya (Bender, 2006: 114).

Studi terhadap kompetensi dan perilaku manusia dalam menggunakan teknologi informasi telah banyak dilakukan dan pada umumnya mengacu pada teori 
kognitif sosial yang dikemukakan oleh Albert Bandura. Bandura (1986), mengajukan konsep self efficacy untuk menjelaskan keyakinan individu akan kemampuan dirinya dalam mengerjakan sesuatu. Compeau and Higgins (1995), mengadopsi konsep self efficacy Bandura untuk menjelaskan kompetensi dan perilaku manusia dalam menggunakan komputer. Konsep Compeau and Higgins ini dikenal sebagai Computer Self Efficacy (CSE). Studi lanjutan berkaitan dengan CSE seseorang telah banyak dilakukan dan pada umumnya mengacu pada dimensi-dimensi CSE yaitu : pengetahuan, keterampilan, sikap, dan kemampuan.

Berdasarkan latar belakang tersebut, akan diangkat tema penelitian tentang "Pengaruh Model Pembelajaran Hypertext dan Hypermedia dengan blended learning terhadap Hasil Belajar Siswa yang memiliki Computer Self Effiacy Berbeda mata pelajaran IPS.".

\section{B. Hypertext dan Hypermedia}

Hypertext dan Hypermedia merupakan salah satu konsep multimedia yang berbasis komputer. Smaldino, et.al (2005) dan Roblyer (2006) mengemukakan bahwa hypertext dan hypermedia adalah software computer yang mengandung komponen multimedia (teks, grafis, video dan audio) yang dikaitkan satu dengan yang lain sedemikian rupa sehingga pengguna mudah berpindah dalam mengakses informasi. Clark dan Mayer (2003) menguraikan secara lebih rinci komponen multimedia menjadi dua, yaitu kata (words) yang bisa berupa narasi atau teks di layar, dan grafis yang terdiri dari gambar ilustrasi, photo, animasi atau media. Dengan demikian, Hypertext dan Hypermedia merupakan multimedia interaktif berbasis komputer termasuk teknologi terpadu, yaitu salah satu komponen kawasan pengembangan dari teknologi pembelajaran. Teknolog terpadu ini mempunyai karateristik khusus yang membedakannya dengan 
multimedia lain, yaitu sifatnya yang non linear, interaktif, integrative dan adaptif. (Seels dan Richey, 1994).

Hypertext dan Hypermedia, demikian juga perangkat pembelajaran untuk e-learning lainnya, disamping memuat konten (isi dan informasi), juga memuat metode pembelajaran untuk membantu pembelajaran (Clark \& Mayer, 2003). Dengan demikian hypertext dan hypermedia tidak semata-mata perangkat yang static, tetapi juga perangkat untuk menyampaikan pembelajaran (delivering). Dalam hal ini, hypertext dan hypermedia bisa merupakan bentuk utuh dari teori desain pembelajaran.

Interaktivitas dan kekayaan format informasi yang dimiliki Hypertext dan Hypermedia menjadikannya sangat fleksibel dimanfaatkan dalam pembelajaran. Empat potensi metode pembelajaran yang dapat disampaikan melalui Hypertext dan Hypermedia/ multimedia interaktif berbasis komputer adalah: (1) visualisasi untuk mendukung penjelasan, (2) pembelajaran menggunakan simulasi untuk mempermudah penguasaan materi, (3) pembelajaran problem solving yang dilengkapi dengan feedback secara otomatis, dan (4) pengintegrasian antara pembelajaran kolaboratif dan mandiri (Kozma \& Russell, 2004; Clark \& Mayer, 2003).

Menurut Gagne dan Briggs (1979: 49-50) ada lima kategori kapabilitas hasil belajar, yaitu: (1) keterampiln intelektual (intelectual skills) (2) strategi kognitif (cognitive strategies), (3) informasi verbal (verbal information), (4) keterampilan motorik (motor skills) dan (5) sikap (attitudes). Sementara Reigeluth (1983: 15) berpendapat bahwa hasil belajar atau pembelajaran dapat juga dikatakan sebagai pengaruh yang memberikan suatu ukuran nilai dari metode (strategi) alternatif dalam kondisi yang berbeda, ada hasil nyata dan diinginkan. Hasil nyata adalah 
hasil-hasil kehidupan nyata dari menggunakan metode (strategi) spesifik dalam kondisi yang spesifik pula. Sedangkan hasil diinginkam adalah tujuan-tujuan (goals) yang umumnya berpengaruh pada pemilihan suatu metode. Ini berarti hasil belajar sangat erat kaitannya dengan metode (strategi) yang digunakan pada sesuatu kondisi pembelajaran tertentu. Ketepatan pemilihan metode atau strategi pembelajaran pada suatu kondisi, maka akabn semakin baik pula hasil belajar yang diperoleh.

Selanjutnya Reigeluth (1983: 94) mengatakakan secara spesifik, hasil belajar adalah suatu kinerja (performance) yang diindikasikan sebagai suatu kapabilitas (kemampuan) yang telah diperoleh. Hasil belajar terebut selalu dinyatakan dalam bentuk tujuan-tujuan (khusus) perilaku (unjuk kerja).

Percival dan Ellington (1984) memberikan pengertian hasil belajar merupakan kapasitas terukur dari perubahan individu yang diinginkan berdasarkan ciri-ciri (sifat-sifat) variabel bawaannya melalui perlakuan/pembelajaran tertentu. Dalam pengertian ini hasil yang diperoleh adalah hasil kegiatan dalam belajar pebelajar dalam bentuk pengetahuan sebagai akibat dari perlakuan/pembelajaran tersebut.

Berdasarkan paparan teori tentang hasil belajar di atas, peneliti membuat definsi konseptual hasil belajar sebagai suatu kesimpulan, bahwa hasil belajar adalah merupakan perilaku berupa pengetahuan, keterampilan, sikap, informasi dan atau strategi kognitif yang baru dan diperoleh pebelajar setelah berinteraksi dengan lingkungan dalam suasana atau kondisi pembelajaran. Pengetahuan, keterampilan, sikap, informasi dan atau strategi kognitif tersebut adalah baru, artinya bukan yang telah dimiliki pebelajar sebelum memasuki kondisi atau situasi pembelajaran dimaksud.

Hasil belajar tersebut bisa juga berbentuk kinerja atau unjuk kerja (performance) yang ditampilkan seseorang setelah selesai mengikuti proses pembelajaran atau pelatihan. Dalam penelitian ini hasil belajar yang akan diukur adalah hasil ranah kognitif pada jenjang pengetahuan, pemahaman, analisis dan evaluasi yang disesuaikan dengan karakteristik mata pelajaran Teknologi Informasi dan Komunikasi (TIK). 


\section{COMPUTER SELF EFFICACY (CSE)}

Menurut Compeau dan Higgins (1995) CSE (computer self efficacy) didefinisikan sebagai judgement kapabilitas seseorang untuk menggunakan komputer/sistem informasi/teknologi informasi. Didasarkan pada teori kognitif social yang dikembangkan oleh Bandura (1986), self efficacy dapat didefinisikan sebagai kepercayaan seseorang yang mempunyai kemampuan untuk melakukan perilaku tertentu. Bandura menyatakan bahwa self efficacy yang dirasakan seseorang, memainkan peran penting dalam mempengaruhi motivasi dan perilaku (Igbaria dan Livari, 1995). Hal ini bukan merupakan judgement pada masa lalu seseorang dalam menggunakan komputer, tetapi menyangkut judgement yang akan dilakukan pada masa depan. Hasil riset Campeau dan Biggins (1995) menunjukkan, bahwa ada tiga faktor yang dapat mempengarubi CSE, yaitu: (1) dorongan dari pihak lain (2) pihak lain sebagai pengguna (3) dukungan.

Dorongan dari pihak lain mengacu pada kelompok dan menggunakan persuasi verbal. Pada faktor kedua, seseorang dapat meningkatkan CSE-nya karena mengobservasi dan meniru model perilaku. Ini merupakan cara yang ampuh untuk mengakuisisi perilaku sebagai model pembelajaran. Sedangkan faktor terakhir yaitu adanya dukungan dari organisasi bagi pengguna komputer yang dapat meningkatkan CSE. Dukungan ini dapat berupa ketersediaan dari pihak organisasi untuk membantu individu yang membutuhkan peningkatan kemampuan dan juga persepsi kemampuan diri.

Compeau dan Biggins juga menjelaskan ada tiga dimensi CSE, yaitu: (1) magnitude (2) strength dan (3) generalibility. Dimensi magnitude mengacu pada tingkat, kapabilitas yang diharapkan dalam penggunaan komputer. Individu yang mempunyai magnitude CSE yang tinggi diharapkan mampu menyelesaikan tugastugas komputasi yang lebih kompleks dibandingkan dengan individu yang mempunyai level magnitude CSE yang rendah karena kurangnya dukungan 
maupun bantuan. Dimensi ini juga menjelaskan, bahwa tingginya magnitude CSE seesorang dikaitkan dengan level yang dibutuhkan untuk memahami suatu tugas. Pada individu yang memiliki level magnitude CSE tinggi mampu menyelesaikan tugas-tugasnya dengan rendahnya dukungan dan bantuan dari orang lain, dibandingkan dengan level magnitude CSE yang rendah. Pada dimensi kedua yakni strength, ini mengacu pada level keyakinan tentang judgement atau kepercayaan individu untuk mampu menyelesaikan tugas-tugas komputasinya dengan baik. Dimensi terakhir adalah generazability yang mengacu pada tingkat judgement user yang terbatas pada domain khusus aktifitas. Dalam konteks komputer, domain ini mencerminkan perbedaan konfigurasi hardware dan software, sehingga individu yang mempunnyai level generazability CSE yang tinggi diharapkan dapat secara kompeten menggunakan paket-paket software dan sistem komputer yang berbeda. Sebaliknya tingkat generazability CSE yang rendah menunjukkan kemampuan individu dalam mengakses paket-paket software dan sistem komputer secara terbatas.

Marakas et al, (1998) dalam Agarwal et al. (2000) membagi CSE dalam dua jenis, yaitu general CSE dan spesific CSE. Kedua jenis ini dikonstruksikan berhubungan dengan perbedaan tugas-tugas komputer. Secara umum CSE didefinisikan sebagai judgement keahlian individu dalam menggunakan berbagai aplikasi komputer. Sedangkan spesific CSE adalah kemampuan untuk membuat tugas-tugas yang berhubungan dengan komputer secara spesifik dalam domain komputasi umum.

Ada empat sumber informasi self efficacy menurut Bandura seperti yang dikutip oleh Compeau dan Higgins (1995), yaitu: (1) guided mastery, (2) behavior modeling, (3) social persuasion dan physiological states. Sumber informasi terkuat adalah guide master yang merupakan pengalaman kesuksesan nyata dalam kaitannya dengan perilaku. Interaksi yang berhasil antara individu dengan komputer menyebabkan individu mengembangkan self efficacy-nya lebih tinggi. Dengan demikian praktik langsung merupakan komponen penting dalam pelatihan, sehingga individu membangun kepercayaan diri sesuai dengan kemampuannya. Sumber informasi self efficacy yang kedua adalah pemodelan 
perilaku/behavior modeling, yang meliputi pengamatan terhadap orang lain dalam membentuk perilaku sebagai proses pembelajaran. Compeau dan Higgins (1995) menunjukan bahwa pendekatan pemodelan perilaku untuk pelatihan komputer dapat meningkatkan persepsi self efficacy dan kinerja dalam kontek pelatihan. Sumber yang ketiga adalah pendekataan persuatif dapat juga mempengaruhi self efficacy. Jaminan ulang bagi user yang punya kemampuan tentang teknologi dan menggunakannya dengan sukses dapat membantu para user untuk membangun kepercayaan. Sumber informasi self efficacy yang terakhir adalah physiological states, yang menunjukkan perasaan kecemasan/anxiety yang berdampak negatif terhadap self efficacy. Bandura (1986) menyatakan bahwa individu yang mempunyai perasaan anxiety yang tinggi menunjukkan kurangnya kemampuan diri. Jadi jika individu merasa cemas/anxiety dalam penggunaan komputer, maka is memiliki alasan untuk merasa cemas sehingga menunjukkan self efficacy yang rendah. Berdasarkan penelitian Webster et al. (1990) dalam Compeau dan Higgins (1995) menemukan hasil, bahwa computer anxity dalam proses pelatihan dapat dikurangi dengan mendorong user untuk berperilaku yang menyenangkan.

\section{Pembelajaran dengan Metode Hypertex dan Hypermedia}

Pembelajaran interaktif pada mata pelajaran IPS terpadu yang dapat membantu proses kegiatan belajar mengajar dan mempermudah penyampaian materi pelajaran yang lebih efektif dan efisien serta dapat memotivasi siswa dalam menerima pelajaran. Hypertext dan Hypermedia merupakan salah satu konsep multimedia yang berbasis komputer. Smaldino, et.al (2005) dan Roblyer (2006) mengemukakan bahwa hypertext dan hypermedia adalah software computer yang mengandung komponen multimedia (teks, grafis, video dan audio) yang dikaitkan satu dengan yang lain sedemikian rupa sehingga pengguna mudah berpindah dalam mengakses informasi. Clark dan Mayer (2003) menguraikan 
secara lebih rinci komponen multimedia menjadi dua, yaitu kata (words) yang bisa berupa narasi atau teks di layar, dan grafis yang terdiri dari gambar ilustrasi, photo, animasi atau media. Dengan demikian, Hypertext dan Hypermedia merupakan multimedia interaktif berbasis komputer termasuk teknologi terpadu, yaitu salah satu komponen kawasan pengembangan dari teknologi pembelajaran. Teknolog terpadu ini mempunyai karateristik khusus yang membedakannya dengan multimedia lain, yaitu sifatnya yang non linear, interaktif, integrative dan adaptif. (Seels dan Richey, 1994).

Keberhasilan penerapan metode pembelajaran hypertext dan hypermedia melalui blended learning pada mata pelajaran IPS terpadu ini tidak terlepas dari adanya pandangan konstruktivisme dan prinsip pembelajaran demokrasi dalam metode ini sehingga pembelajaran berlangsung tidak kaku akan tetapi penuh kesepakatan. Implementasi strategi belajar hypertext dan hypermedia melalui blended learning dalam pembelajaran IPS terpadu, secara umum dengan 6 (enam) langkah, yaitu: (1) mengidentifikasi topik dan mengorganisasikan siswa ke dalam kelompok dalam beberapa computer (para siswa menelaah sumber-sumber informasi, memilih topik, dan mengkategorisasi saran-saran; para siswa bergabung ke dalam kelompok belajar dengan pilihan topik yang sama; komposisi kelompok didasarkan atas ketertarikan topik yang sama dan heterogen; guru membantu atau memfasilitasi dalam memperoleh informasi), (2) merencanakan tugas-tugas belajar (direncanakan secara bersama-sama oleh para siswa dalam kelompoknya masing-masing, yang meliputi: apa yang kita selidiki; bagaimana kita melakukannya, siapa sebagai apa pembagian kerja; untuk tujuan apa topik ini diinvestigasi), (3) melaksanakan investigasi (siswa mencari informasi, menganalisis data, dan membuat simpulan; setiap anggota kelompok harus berkontribusi kepada usaha kelompok; para siswa bertukar pikiran, mendiskusikan, mengklarifikasi, dan mensintesis ide-ide), (4) menyiapkan laporan akhir (anggota kelompok menentukan pesan-pesan esensial proyeknya; merencanakan apa yang akan dilaporkan dan bagaimana membuat presentasinya; membentuk panitia 
acara untuk mengkoordinasikan rencana presentasi), (5) mempresentasikan laporan akhir (presentasi dibuat untuk keseluruhan kelas dalam berbagai macam bentuk; bagian-bagian presentasi harus secara aktif dapat melibatkan pendengar (kelompok lainnya); pendengar mengevaluasi kejelasan presentasi menurut kriteria yang telah ditentukan keseluruhan kelas), (6) evaluasi (para siswa berbagi mengenai balikan terhadap topik yang dikerjakan, kerja yang telah dilakukan, dan pengalamanpengalaman afektifnya; guru dan siswa berkolaborasi dalam mengevaluasi pembelajaran; asesmen diarahkan untuk mengevaluasi pemahaman konsep dan keterampilan berpikir kritis). Dalam hypertext dan hypermedia melalui blended learning tersebut, MTs Surya Buana Malang sudah melaksanakannya dengan baik.

\section{Aktivitas Siswa dalam Pembelajaran IPS Terpadu dengan Metode hypertext dan hypermedia melalui blended learning}

Pembelajaran IPS terpadu ini mampu meningkatkan kreativitas siswa di kelas, khususnya dalam proses pembelajaran berlangsung. Sebagaimana awal mulanya dimulai oleh guru dengan bentuk; pertama, guru memberikan kesempatan bagi siswa untuk memberi kontribusi apa yang akan mereka selidiki. Kelompok dibentuk berdasarkan heterogenitas. Dengan pembagian kelompok tersebut, para siswa mampu meningkatkan prestasi yang mereka milikinya, karena dengan pembelajaran tersebut, mereka bisa berkreasi sesuai dengan kemampuan yang mereka miliki.

Kedua, kelompok akan membagi sub topik kepada seluruh anggota. Kemudian membuat perencanaan dari masalah yang akan diteliti, bagaimana proses dan sumber apa yang akan dipakai.

Ketiga, siswa mengumpulkan, menganalisis, dan mengevaluasi informasi, membuat kesimpulan dan mengaplikasikan bagian mereka ke dalam pengetahuan baru dalam mencapai solusi masalah kelompok.

Keempat, setiap kelompok mempersiapkan tugas akhir yang akan dipresentasikan di depan kelas. Sehingga setiap kelompok melakukan sebuah diskusi kecil dengan teman-temannya sebelum melakukan atau mempresentasikan didepan kelompok yang lain. Ternyata pembelajaran ini sangat efektif dan mampu meningkatkan prestasi mereka kepada yang lebih baik. 
Kelima, siswa mempresentasikan hasil kerjanya. Kelompok lain tetap mengikuti. Keenam, soal ulangan mencakup seluruh topik yang telah diselidiki dan dipresentasikan. Pembelajaran IPS terpadu ini memang sangat berat khususnya bagi par guru untuk mengelola sistem pembelajaran tersebut, namun dalam sisi lain mampu dan bisa mengepresikan kualitas dari para siswa terpendam.

Dengan enam tahapan kemajuan siswa dalam pembelajaran kooperatif dengan metode hypertext dan hypermedia melalui blended learning pada mata pelajaran IPS terpadu MTs Surya Buana Malang tersebut di atas mampu meningkatkan prestasi siswa yang lebih baik.

Model pembelajaran yang akan dipakai dalam pembelajaran IPS terpadu dengan kompetensi dasar. Menganalisis hubungan antara perkembangan pahampaham baru dan transporasi sosial dengan kesadaran dan pergerakan kebangsaan adalah metode hypertext dan hypermedia melalui blended learning. Namun sebelum dijabarkan apa itu metode hypertext dan hypermedia melalui blended learning akan ditinjau terlebih dahulu mengenai munculnya teori metode hypertext dan hypermedia melalui blended learning itu sendiri. Metode hypertext dan hypermedia melalui blended learning Hypertext dan Hypermedia merupakan salah satu konsep multimedia yang berbasis komputer. Smaldino, et.al (2005) dan Roblyer (2006) mengemukakan bahwa hypertext dan hypermedia adalah software computer yang mengandung komponen multimedia (teks, grafis, video dan audio) yang dikaitkan satu dengan yang lain sedemikian rupa sehingga pengguna mudah berpindah dalam mengakses informasi. Clark dan Mayer (2003) menguraikan secara lebih rinci komponen multimedia menjadi dua, yaitu kata (words) yang bisa berupa narasi atau teks di layar, dan grafis yang terdiri dari gambar ilustrasi, photo, animasi atau media. Dengan demikian, Hypertext dan Hypermedia merupakan multimedia interaktif berbasis komputer termasuk teknologi terpadu, yaitu salah satu komponen kawasan pengembangan dari teknologi pembelajaran. Teknolog terpadu ini mempunyai karateristik khusus yang membedakannya dengan multimedia lain, yaitu sifatnya yang non linear, interaktif, integrative dan adaptif. (Seels dan Richey, 1994).

Hypertext dan Hypermedia, demikian juga perangkat pembelajaran untuk elearning lainnya, disamping memuat konten (isi dan informasi), juga memuat metode 
pembelajaran untuk membantu pembelajaran (Clark \& Mayer, 2003). Dengan demikian hypertext dan hypermedia tidak semata-mata perangkat yang static, tetapi juga perangkat untuk menyampaikan pembelajaran (delivering). Dalam hal ini, hypertext dan hypermedia bisa merupakan bentuk utuh dari teori desain pembelajaran.

penerapan metode mengajar ini dalam mengajar, bahwa dalam metode ini berjalan dalam fase yang berbeda. Penerapan dimulai dengan menghadapkan siswa kepada masalah, yang dari sumber-sumber yang berbeda. Masalah itu bisa dalam bentuk verbal ataupun merupakan bagian dari suatu pengalaman. Hal itu dapat disediakan oleh guru ataupun muncul dari kelas. Jika siswa bereaksi terhadap masalah tersebut, maka guru menarik perhatian mereka terhadap reaksi yang berbeda. Jika siswa telah menunjukkan miant terhadap reaksi-reaksi yang berbeda itu maka guru mendorong siswa untuk merumuskan masalah untuk diri mereka. Setelah merumuskan siswa mengkajinya dengan memperhatikan peranan dan mengorganisasi dirinya. Kemudian bertindak dan melaporkan hasilnya inilah yang mungkin merupakan cikal-bakalnya pendekatan proses yang lazim digunakan dalam pelajaran Ilmu Pengetahuan Sosial (IPS) terpadu dan merupakan salah satu ciri kurikulum tahun 1975.

Adapun sintaks dalam proses pembelajarn tersebut dapat dijabarkan sebagai berikut: 1) Student encountrn puzzling stuation, 2) Student explore to the stuation, 3) Student formulate study talk and organize for study (problem definition role, assigments, etc), 4) Endependent end growth study, 5) Study alalyze programs end producs, dan 6) Recycle activity.

Akhirnya kelompok menilai keputusan-keputusan dalam kaitannya dengan tujuan kelompok semula. Beberapa hal yang dapat ditarik dari metode ini adalah:

Pertama, sistem sosial. Metode ini adalah demokratik. Masalah dimunculkan oleh guru atau ditentukan oleh guru sebagai objek pengajaran. Guru dan siswa mempunyai status yang sama.

Kedua, prinsip-prinsip reaksinya adalah guru bertindak sebagai konselor tanpa mengganggu struktur yang ada. 
Ketiga, sistem yang menunjang. Dukungan yang diberikan oleh guru ekstensif dan responsif terhadp kebutuhan siswa. Perpustakaan yang baik merupakan kebutuhan yang esensi bagi model tersebut. Di samping itu hubungan dan kontakkontak dengan lembaga-lembaga di luar sekolah dan juga pribadi-pribadi diperlukan oleh siswa untuk memecahkan masalah yang menjadi fokus pelajaran.

Keempat, metode yang dapat digunakan untuk semua bidang pelajaran dan juga dapat digunakan sebagai aspek di dalam merumuskan dan memecahkan masalah. Dengan melihat bahwa ada berbagai keuntungan dari model ini maka juga dapat diterapkan dalam pengajaran IPS yang sering menggunakan metode pemecahan masalah.

Dengan demikian, metode hypertext dan hypermedia dapat juga diterapkan pada proses pembelajaran IPS terpadu, karena metode ini berorientasi terhadap pemecahan masalah. Jadi siswa dapat mencari makna terhadap proses pembelajaran IPS terpadu dan model ini sesuai dengan apa yang diharapkan, bahwa belajar menekankan pada murid agar dapat mengkonstruksi pengetahuan melalui hypertext dan hypermedia interaksi sosial dengan orang lain.

\section{E. Keterampilan penggunaan Hypertext dan Hypermedia Siswa dalam Pembelajaran \\ Salah satu bentuk pembelajaran Hypertext dan Hypermedia merupakan} multimedia interaktif berbasis komputer termasuk teknologi terpadu, yaitu salah satu komponen kawasan pengembangan dari teknologi pembelajaran. Teknolog terpadu ini mempunyai karateristik khusus yang membedakannya dengan multimedia lain, yaitu sifatnya yang non linear, interaktif, integrative dan adaptif. (Seels dan Richey, 1994).

Hypertext dan Hypermedia, demikian juga perangkat pembelajaran untuk elearning lainnya, disamping memuat konten (isi dan informasi), juga memuat metode pembelajaran untuk membantu pembelajaran (Clark \& Mayer, 2003). Dengan demikian hypertext dan hypermedia tidak semata-mata perangkat yang static, tetapi juga perangkat untuk menyampaikan pembelajaran (delivering). Dalam hal ini, 
hypertext dan hypermedia bisa merupakan bentuk utuh dari teori desain pembelajaran.

Interaktivitas dan kekayaan format informasi yang dimiliki Hypertext dan Hypermedia menjadikannya sangat fleksibel dimanfaatkan dalam pembelajaran. Empat potensi metode pembelajaran yang dapat disampaikan melalui Hypertext dan Hypermedia/ multimedia interaktif berbasis komputer adalah: (1) visualisasi untuk mendukung penjelasan, (2) pembelajaran menggunakan simulasi untuk mempermudah penguasaan materi, (3) pembelajaran problem solving yang dilengkapi dengan feedback secara otomatis, dan (4) pengintegrasian antara pembelajaran kolaboratif dan mandiri. Metode group investigation merupakan model pembelajaran kooperatif yang kompleks karena memadukan antara prinsip belajar kooperatif dengan pembelajaran yang berbasis konstruktivisme dan prinsip pembelajaran demokrasi. Metode group investigation dapat melatih siswa untuk menumbuhkan kemampuan berfikir mandiri. Keterlibatan siswa secara aktif dapat terlihat mulai dari tahap pertama sampai tahap akhir pembelajaran akan memberi peluang kepada siswa untuk lebih mempertajam gagasan dan guru akan mengetahui kemungkinan gagasan siswa yang salah sehingga guru dapat memperbaiki kesalahannya.

Dalam kaintannya dengan mengajar IPS terpadu, maka guru dapat mengembangkan metode mengajarnya yang dimaksudkan sebagai upaya mempengaruhi perubahan yang baik dalam perilaku siswa. Pengembangan model tersebut adalah dimaksudkan untuk membantu guru meningkatkan kemampuannya untuk lebih mengenal siswa dan menciptakan lingkungan yang lebih bervariasi bagi kepentingan belajar siswa.

Desain pembelajaran pada penelitian ini merujuk pada standar standar kompetensi (SK); menganalisis perkembangan bangsa Indonesia sejak masuknya pengaruh Barat dengan penduduk Jepang, dengan kompetensi dasar (KD) yaitu; menganalisis hubungan antara perkembangan paham-paham baru dan transformasi sosial dengan kesadaran dan pergerakan kebangsaan. Adapun indikator yang akan dipelajari adalah kemampuan siswa dalam menganalisis bentuk-bentuk organisasi pada masa pergerakan kebangsaan di Indonesia. 
Sesuai dengan apa yng dipaparkan pada bagian sebelumnya, bahwa desain yang digunakan dalam proses pmbelajaran yang terkait dengan kompetensi dasar di atas adalah merujuk pada pendekatan yang dilakukan Vygotsky, melalui pendekatan atau metode hipertex dan hypermedia dalam proses pengajaran. Penulis merujuk pada pendekatan ini dengan alasan bahwa dalam proses pembelajaran IPS terpadu yang sifatnya adalah melakukan pemecahan terhadap suatu masalah akan mampu menciptakan suasana belajar yang dirasa sangat kondusif apabilan menggunakan pendekatan atau metode hipertex dan hypermedia karena pada dasarnya pembelajaran IPS terpadu akan lebih bermakna apabila dilakukan dengan proses belajar kolaboratif, jadi siswa yang belum jelas akan suatu permasalahan maka ia akan bertanya dengan teman satu kelompoknya yang dirasa sudah memahami suatu konsep, dan dekimian juga gurunya yang selalu siap menjadi fasilitator bagi siswa yang mengalami permasalahan dalam proses pembelajaran yang terkait dengan kompetensi dasar tersebut.

Hal ini sesuai dengan pembelajaran konstruktivisme yang diutarakan oleh Vygotsky, bahwasanya siswa akan mudah memahami suatu konsep apabila dalam proses belajar menekankan pada murid agar dapat mengkonstruksi pengetahuan melalui media computer interaksi sosial dengan orang lain. Dengan demikian, siswa dapat dikatakan sudah melakukan proses belajar bermakna, karena tidak saja terkait dengan ketercapaian materi belajar, namun siswa juga belajar hidup sosial ketika melakukan diskusi kelompok. Untuk menghasilkan tujuan yang diharapkan, jika pada bagian sebelumnya telah dijelaskan pendekatan apa yang digunakan dalam desain pembelajaran sejarah terkait dengan kompetensi dasar menganalisis hubungan antara perkembangan paham-paham baru dan transformasi sosial dengan kesadaran dan pergerakan kebangsaan. Maka berikutnya akan dibahas mengenai metode apa yang akan digunakan dalam desain pembelajaran tersebut.

Dengan melihat pandangan di atas, sekiranya metode tersebut cocok untuk diterapkan pada proses pembelajaran IPS terpadu karena tujuan dari proses pembelajaran IPS terpadu adalah mendidik dan membekali siswa dengan seperangkat pengetahuan, sikap, nilai, moral, dan keterampilan untuk memahami lingkungan sosial masyarakat dapat dicapai. Dengan menggunakan hipertex dan 
hypermedia dapat menjadikan pembelajaran IPS terpadu lebih menarik, penuh tantangan dan bergairah dalam mempelajarinya, sehingga timbul harapan adanya pengembangan potensi siswa secara optimal dalam belajar mandiri serta belajar bersama untuk mencapai tujuan bersama.

\section{F. kesimpulan}

Pertama, dalam keberhasilan penerapan metode pembelajaran Hypertex dan Hypermedia melalui Blended Learning pada mata pelajaran IPS terpadu tidak terlepas dari adanya pandangan konstruktivisme dan prinsip pembelajaran demokrasi dalam metode ini sehingga pembelajaran berlangsung tidak kaku akan tetapi penuh kesepakatan.

Kedua, aktivitas siswa dalam pembelajaran metode Hypertex dan Hypermedia melalui Blended Learning dengan membagi sub topik kepada seluruh anggota. Kemudian membuat perencanaan dari masalah yang akan diteliti, bagaimana proses dan sumber apa yang akan dipakai. Siswa mengumpulkan, menganalisis, dan mengevaluasi informasi, membuat kesimpulan dan mengaplikasikan bagian mereka ke dalam pengetahuan baru dalam mencapai solusi masalah kelompok. Terakhir para siswa mempresentasikan hasil kerjanya dan kelompok lain tetap mengikutinya.

Ketiga, keterampilan kooperatif siswa dalam metode Hypertex dan Hypermedia melalui Blended Learning pada mata pelajaran IPS terpadu sama-sama melakukan proses belajar tersebut dengan penuh bermakna, karena tidak saja terkait dengan ketercapaian materi belajar, namun siswa juga belajar mengoperasikan computer dengan baik dan hidup sosial ketika melakukan diskusi kelompok.

\section{DAFTAR PUSTAKA}

Agarwal, Rithu, V. Sambamurthy and R.M. Stair. 2000. "Reserach Report: The Solving Relationship between General and Specific Computer Self Efficacy - An Empirical Assessment", Information Systems Research, Vol. 11,No. 4.

Bender, D. M., \& Vredevoogd, J. D. 2006. Using Online Education Technologies to Support Studio Instruction. Educational Technology E Society, 9 (4), 114-122.

Bersin, Josh. 2004. The Blended Beaming Book: Best Bractices, Proven Methodologies, and Lessons Learned. San Francisco: Pfeiffer 
Clark, R. C \& Mayer, R. E. 2003. E-Learning and The Science of Instruction. San Francisco: Jossey-Bass/Pfeiffler.

Compeau, Deborah R. and C.A. Higgins. 1995. "Computer Self Efficacy: Development of Measure and Initial Test", MIS Quartely, Vol.19, No.12.

Dabbagh, N. \& Bannan-Ritland, B. 2005. Online Learning, Concepts, Strategies and Application. Upper Saddle River: Pearson Education Inc.

Degeng, INS., 1989. Teori Pembelajaran: Taksonomi Variabel. Jakarta: Program Magister Manajemen Pendidikan Universitas Terbuka.

Dwiyogo, Wasis D. 2011. Pembelajaran Berbasis Blended Learning. Makalah disampaikan pada Seminar dan Lokarkarya Peningkatan Kualitas Pembelajaran melalui Blended Learning Model, FKM PPS Universitas Negeri Malang, 26 Maret 2011.

Elliot, S. N., Kratchwill, T. R., Cook, J. L., \& Traver, J. E. 2000. Educational Psychology: Effective Teaching, Effective Learning. Boston: Mc.Graw-Hill Higher Education.

Gagne, R. M \& Briggs, L. J. 1979. Principles of Instructional Design: New York; Holt, Pinehart and Winstone.

Gallegher, D. 2007. Learning Styles, Self-Efficacy and Satisfaction with Online Learning: Is online Learning for Everyone?. Dissertation. Graduate College of Bowing Green State University.

Igbaria, M., dan J. Livari. 1995. "The Effect of Self Efficacy on Computer Usage", Omega, Vol.23, No.6.

Kerlinger, F. N. 1986. Fondations of Behavioural Research. New York: CBS College Publishing.

Kozma, R. B., \& Russell, J. 2004. Multimedia Learning of Chemistry. Dalam R. E. Mayer. Cambridge Handbook of Multimedia Learning, (online), (http://chemsense.org/abaout/papres/KozmaRussellMultimedia2004.pdf, diakses 4 Agustus 2007).

Percival, F \& Ellington, H. Buku Pegangan Teknologi Pendidikan, (Terjemahan Sudjawro dan sarawati). London: Kogan Page (tanpa tahun)

Reigeluth, C. M. 1983. Instructional-Design Theories and Models: An Overview of their Current Status. New jersey: Lawrence Erlbaum Associates, Inc.

Roblyer, M. D. 2006. Integrating Educational Technology into Teaching (Foutrh Ed.) Upper Saddle River: Pearson Education Inc.

Schunck, D. H. 1983. Ability versus Effort Attrributional Feedback: Differential Effect, Effect on Self-Efficacy and Achievement. Journal of Educational Psychology, 76, 3, 848-856. 
Seels, Berbara B. \& Richey, Rita C. 1994. Instructional technology: The Definition of Domain of The Field. Washington DC,: Association for Educational Communications naf Technology (AECT).

Sheng, Y.H.P., J.M. Pearson; L. Crosby. 2003. 'Organization Culture and Emplotee's Computer Self Efficacy: an Emperical Study", Information Resources Management Journal. Vol. 16, No. 3.

Smaldino, S. E., Russel, J. D., Heinich, R. \& Molenda, M. 2005. Instructional Technology and Media for Learning (8 $8^{\text {th }}$ Ed.). Upper Saddle River: Pearson Education, Inc.

So, H.-J., \& Bonk, C. J. 2010. Examining the Roles of Blended Learning Approaches in Computer-Supported Collaborative Learning (CSCL) Environments: A Delphi Study. Educational Technology E Society, 13 (3), 189-200.

Stone, N., V Arunachalam \& John S. Chandler. 1996. "Crosscultural Comparisons: An Empirical Investigationf Knowledge, Skill, Self Efficacy and Computer Anxiety in Accounting Education", Issues lit Accounting Education. Vol. 11, No.2.

Thorne, Kaye. 2003. Blended Learning: How to integrate online \& traditional learning. London: Kagan Page Limited.

Tuckman, B.W. 1999. Conducting Educational Research. (fifth edition). Orlando: Harrcourt Brace College Publisher.

Wijaya, Tony. 2003. Pengaruh Computer Anxiety terhadap Keahlian Dosen dalam Penggunaan Komputer: Perspektif Gender. Skn'psl S1-Fe UAJY. tidak dipublikasikan. 